\title{
Аделаида Смољска
}

\section{ЕВОЛУЦИЈА ТВОРБЕ РЕЧИ У СРПСКОМ ЈЕЗИКУ И ЮЕНО ПРОУЧАВАҢЕ}

Творба речи је релативно млада посебна област лингвистике, која има неколико смерова, неколико аспеката проучавања.

Први радови из творбе речи у славистици настали су у XIX веку. То се односи не само на Србију, већ и на друге словенске земље.

Прави почетак научног развоја теорије и праксе у области творбе речи, како кажу слависти, припада крају прве половине XX века (упор. радове В. В. Виноградова, Р. Бошковића, В. Дорошевског и др.). Крајем XX века можемо рећи да је словенска дериватологија током последњих педесет година постигла велике успехе, али углавном у области синхроне деривације.

Од времена прве упоредне граматике Ф. Миклошића изазива пажњу упоредно проучавање творбе речи у словенским језицима. Мада се рад у том правцу сада интензивира кроз међународне научне скупове (Conоставительное изучение... 1984), постоји и песимистичко мишљење да је упоредно-историјска словенска творба речи ствар будућности (Толстой 1984).

У вези с упоредном творбом речи актуелан је проблем истраживања дијахроних константа, тј. истих промена у деривационом систему које се врше на терену различитих словенских језика у различито време. Појава дијахроних константа често је везана за такозване прасловенске импулсе (упор. конкуренцију суфикса са фонетским елементима „к” и „й, експанзију „к” - суфикса у различитим словенским језицима). Временски различите константе могу бити изазване и језичким универзалијама (упор. дужину суфикса, употребу двоструких форманата са консонантским и вокалним почетком: -тель и -итель у руском, -льа и -иль у српском и слично). Дијахроне константе словенске творбе речи могу бити утврђене само на основу историјске деривације у сваком словенском језику, нажалост, та област је најмање проучена у славистици.

Ипак, сада су актуелна три главна аспекта проучавања творбе речи: синхронијска дериватологија, тј. синхронијско описивање творбених система словенских језика, упоредна или, како неки кажу, упоредно-ис- 
торијска словенска дериватологија, дијахронијска дериватологија, која проучава еволуцију творбе речи у сваком словенском језику, нарочито у књижевној пројекцији. Последњем смеру се придружује и ареална творба речи, због тога што је синхроно стање сваког дијалекта локално изражена дијахронија.

У србистици почетак синхронијског описивања творбе речи везан је за радове Вука Караџића и Ђуре Даничића. У реформи В. Караџића једно од централних места заузимала је идеја формирања лексичког фонда српског књижевног језика на основу народних говора и усмене књижевности. Ово је изазвало потребу описивања творбених елемената народног језика, што је било потребно за стварање нових речи према народним моделима. Тада се појавио познати Вуков чланак Главна свршивана суштестивителни и прилагателни имена у српском језику (Караџић 1964; о српској творби речи писао је и Јован Хаџић, в. Кашић 1985), где је заснивач новог књижевног језика приказивао живе наставке, нпр. 97 суфикса српских именица. Такође, веома је важан Караџићев творбени коментар у предговору његовог превода Новог завета, где је дозвољавао употребу такозваних словенских књижевних суфикса, нпр. суфикса -тељь (упор. о томе: Цвијић 1963, Дмитриев и Сафронов 1985).

За даље разрађивање српске творбе речи били су врло корисни чланци и радови Ђуре Даничића (нпр. Српска деминуиија и аугментација - Даничић 1860), а нарочито његова књига Основе српскога или хрватскога језика (Даничић 1876), где су именице биле груписане према суфиксима. Тај Даничићев рад до сада су успешно користили дериватолози-србисти не само у Србији, већ и у Пољској и Русији.

Средином XX века појавили су се целовити описи српске творбе речи, које су написали водећи српски лингвисти - академици А. Белић (Белић 1949) и М. Стевановић (Стевановић 1964). Мада је у овим радовима било речено да се изведеница не састоји само од наставака, већ и од творбене основе, ипак су главни објекат анализе творбеног система код Белића и Стевановића били наставци, тј. суфикси.

Наравно, осим поменутих целокупних описа система творбе речи у другој половини XX века појавило се доста чланака и радова, у којима су се проучавали различити суфикси именске и глаголске творбе, творбени модели, творбене категорије. Како нам се чини, најважнију улогу у развоју науке о творби речи у српском језику одиграли су радови једног од најталентованијих дериватолога XX века, једног од оснивача упоредног проучавања словенске деривације Радосава Бошковића, нарочито његова докторска дисертација Развитак суфикса у јужнословенској језичкој заједнищи (Бошковић 1936). Како је тачно рекла Јелка Матијашевић, 
„централно место у стваралачком опусу проф. Бошковића заузима творба речи - као компаративна проблематика" (Матијашевић 1978).

Бошковић је ушао у славистику кад је наука о суфиксима после дужег застоја покушавала да отвори нове перспективе. О изузетном доприносу проф. Бошковића упоредној словенској дериватологији изречено је доста похвала. Али ипак треба нагласити да је Радосав Бошковић био први међу компаративистима који је истакао захтев да се у упоредној граматици словенских језика за решавање различитих глотогенетских проблема и класификационих шема користе, поред фонолошког и морфолошког, и дериватолошки критеријуми. У својим радовима Р. Бошковић се увек налазио на позицијама динамике творбених односа и творбеног система; пажњу је поклањао не само облику изведеница, већ и семантици деривата.

Бошковићеву компаративну анализу прихватили су касније његови следбеници: Јелка Матијашевић у компаративним студијама семантичке творбе речи на материјалу српског и руског језика, Милан Стакић у проучавању морфолошке компоненте творбе речи у јужнословенским језицима (Стакић 1988) и др. Упоредну творбу речи често примењују русисти у Србији и србисти у Русији.

Радова из деривационе историје српског књижевног језика у савременој србистици има мање него из упоредне дериватологије. Ипак и малобројна дијахронијска истраживања творбе речи, како нам се чини, такође су везана за научно стваралаштво првог дијахроничара Ђуре Даничића, историчара српског језика Александра Белића и најбољег дериватолога Радосава Бошковића.

Познато је да је Р. Бошковић много урадио за творбену историју јужнословенских језика. Он је проучавао конкуренцију наставака истог значења и употребе, што је основни чинилац историјског развитка деривационог система. Од дијахронијских радова друге половине XX века у области творбе речи издвојићемо само два. Хронолошки треба почети од рада Олге Ристић Лексичко-семантичке одлике творбе речи у неких српских и хрватских песника (Ристић 1969-1970). Лингвисти кажу да историјска творба према карактеру истраживања може бити како синхронијски статична, тако и дијахронијски динамична, када се ради тумачења тенденција еволуције језика проучавају разновременске појаве и чињенице.

У раду О. Ристић поређење развоја творбе речи одвија се, како ми сада кажемо, на материјалу два разновременска синхронијска пресека: први пресек односи се на период Вукове реформе, а други на период деловања књижевника - Вукових следбеника. У једном од закључака овога 
рада обратићемо пажњу на то како су књижевници поствуковске епохе искоришћавали народне творбене елементе, од којих су неки касније престали да буду тако активни. На пример, изведенице са суфиксом -љ-а $(-и љ-a)$ нису биле само општекњижевни, него и ауторски неологизми: код J. Ј. Змаја О. Ристић је фиксирала примере гледала, просиља, читаља. У француско-српском речнику из 1875-1885 налазе се примери говориља и гладиља, док код Милана Милићевића налазимо примере памтила, твориль (у предметном значењу). Конкуренција суфикса и промене у социуму у правцу зближавања мушког и женског пола касније су одвеле суфикс-ль- $(-и љ-a)$ у састав мање активних форманата.

Други значајни рад из дијахронијске творбе речи је докторска дисертација Боже Ћорића на материјалу српских феминалних суфикса и модела са њима, ексцерпираних из Рјечника ЈАЗУ, који је почео да се ствара под руководством Ђ. Даничића. Грађа коју је прикупио Б. Ћорић оријентисана је, за разлику од рада О. Ристић, на велико временско раздобље. Та грађа је омогућила истраживачу да први пут у србистици тачно хронолошки одреди време појављивања различитих феминалних суфикса и наставака са њима у српским књижевним текстовима. Б. Ћорић се у свом раду користио и дијалекатском грађом. Ово је био пут за други важан и нов закључак: у којим дијалектима су познати и продуктивни одређени именски суфикси и творбени типови с њима. На пример, поводом дијалекатске употребе модела са формантом - киға Б. Ћорић каже: „Потврде долазе из штокавских дијалеката, сасвим ретко из чакавског, а нема их из кајкавског" (Ћорић 1982, стр. 133). Ћорићев рад је у неку руку бар делимично попунио празнину из можда већ припремљених, али још необјављених специјалних радова о ареалној творби речи.

За мали број радова из историјске творбе речи има разлога, нарочито ако ту особину србистике упоредимо са другим гранама славистике. Још је В. В. Виноградов истакао да је творба речи истовремено везана и за морфологију и за лексику. Везаност за лексику толико повећава опсег материјала (при чему је важна свака изведеница) да се до сада ниједна национална славистика не може похвалити потпуним описом еволуције творбе речи у свом језику. Има радова из историје творбе речи у србистици, бугаристици, русистици, полонистици, бохемистици, украјинистици итд., али потпуни опис еволуције творбе речи није урадила ниједна национална екипа слависта.

Није случајно што творба речи, за разлику од фонетике, обично не спада у широко схваћену такозвану историјску граматику појединих словенских језика. Слависти дијахроничари, проучавајући творбу речи у свом језику, морају користити искуство лингвиста из других земаља. 
Дијахронијска творба речи поставља пуно проблема. Најпре треба одредити шта ће бити објекат дијахронијског описа: наставак (суфикс), модел (творбени тип, творбена категорија или чак целовит систем творбе речи). Један од најпознатијих украјинских дериватолога И. И. Ковалик још је 1958. године (Ковалик 1958) рекао да је за упоредну творбу речи корисније узети целовиту творбену категорију (nomina agentis, nomina loci, nomina feminina и слично). Томе треба додати да је за дијахронијску творбу речи овај поступак готово обавезан, зато што се у творбеној категорији најпре види конкуренција суфикса истог значења али различитог облика, без чега нема развоја творбеног система, његове еволуције. За законе развитка творбе речи важи и хомонимија творбених средстава, али тај чинилац заузима друго место после конкуренције суфикса.

Осим објекта творбеног описа важно је такође одредити и границе дијахронијског описа творбе речи. То зависи од тога како истраживач интерпретира историју књижевног језика. Могу се узети велики и мали кругови (описи) проучавања творбене еволуције. Руска бохемисткиња Галина Нешчименко проучавала је чешке деминутиве од првих књижевних споменика до друге половине XX века. Међутим, руска лингвистика има и колективну монографију Изменения в словообразовании и формах существительного и прилагательного в русском литературном языке XX века (1964), која се односи на постпушкински период, што је врло важно за историју руског књижевног језика.

Србистици су потребни радови из творбе речи са великим и малим дијахронијским амплитудама. Актуелни су радови који би истраживали еволуцију различитих система новог књижевног језика од Вука Караџића до садашњег времена. Тај циљ је био формулисан пре скоро четрдесет година. Поменимо у том контексту чланак Милке Ивић Једно поређене Вукова језика с нашим данашњим књижевним језиком (М. Ивић 1957).

За проучавање творбене еволуције у поменутом правцу, тј. само историје књижевног језика у ново време, врло је важан проблем утврђивања такозваних синхроних пресека, описивања творбених система у сваком пресеку и најзад њиховог унутарјезичког поређења. Проучавајући радове србиста о развоју српског књижевног језика у ново време (П. Ивић, Ј. Јерковић, А. Младеновић, Н. Толстој, П. А. Дмитријев, В. Гутков и др.) ми смо у свом докторском раду Развитак именске творбе речи у српскохрватском књижевном језику најпре издвојили два синхронијска пресека: први - време реформе В. Караџића, признавања те реформе и прве кодификације закона новог књижевног српског језика (XIX в.), и други - наставак развоја различитих нивоа српског језика, укључујући и деривациони систем (XXв.). 
Еволуција творбе речи у књижевном језику не може се описивати формално, само путем издвајања творбених модела и њихове каталогизације. Дериватолог-дијахроничар треба стално да има у виду везу између творбених процеса и главних тенденција развоја књижевног језика у сваком периоду, односно у сваком синхроном пресеку. Ако први период у историји српског књижевног језика новог времена (XIX в.), карактерише интензивна тенденција демократизације и покњижевљења (олитературивания) народних творбених средстава, онда се у другом синхроном пресеку (XX в.; Смольская 1993) одвија паралелно функционисање двеју тенденција - демократизације, чувања народних основа, и интелектуализације књижевног језика, када се у великим размерама врши позајмљивање лексике из европских, такозваних светских језика, што доводи до усвајања нових творбених модела, до промене продуктивности суфикса, до новог начина номинације.

Као илустрацију навешћемо само један пример. Међу народним формантима који су ушли у књижевни језик за време Караџићеве реформе налази се и релативно млад феминални суфикс -киња, који је настао путем контаминације суфикса - $-a$ и -иғ $a$; као самосталан суфикс он се фиксира од XVI в. У предвуковској епоси тај суфикс није имао стабилну традицију књижевне употребе (уп. такође суфиксе -љ-а, -ач и др.). У народном језику био је у употреби у nomina regionalia, у лексици из породичног живота (упор. безроткиға, једнолеткиға, нахранкиға и сл.), у митологији за именовање врста вила (упор. вила језеркиюа, планинкиюа, поморкиға и сл.). Међутим, у књижевном језику суфикс -киғ-а шири границе свог функционисања, односно свој творбени ареал, активно се искоришћава у хибридним изведеницама: најпре у изведеницама типа Франиускиға, затим адвокаткиюа, кандидаткиюа (М. Милићевић), касније телефонисткиға, клавиристкиюа (и пијанисткиға), матуранткина итд.

Тај суфикс је имао неке особине које су допринеле да он постане један од продуктивних феминалних суфикса српског књижевног језика. Прво, он није био стилски маркиран, имао је само денотативно значење: друго, скоро да није имао препрека у морфонолошком избору (упор. суфикс -к-а који је углавном тражио творбене основе на сонант); треће, суфикс -кин-а био је у ствари моносемантичан, учврстио се у књижевном језику у XX в. углавном као феминални суфикс у хибридним моделима на -am, -ucm, -ант (-ент) - (упор. суфикс -иน-а полисемантичког карактера).

И на крају две напомене. Мада смо у овом раду најпре издвојили два синхрона пресека, прикупљена грађа из нових речника, а такође и књижевних текстова XIX и XX века, захтевала је прецизирање наше класи- 
фикационе шеме. Промене у именском творбеном систему, нпр. у творбеној категорији nomina feminina, почеле су да се појављују већ у другој половини XIX века. Овај временски период - друга половина и крај XIX века - треба сматрати иницијалним периодом деривационе еволуције XX в. Можда то није случајно. У време развоја такозване екавске верзије српског књижевног језика промене се нису вршиле само у ортоепској сфери, већ и у другим нивоима српског књижевног језика, укључујући и деривациони систем.

Друга напомена треба да нас врати разговору о дијахроним константама, које можемо утврдити само кроз дијахронијско проучавање појединих словенских језика. Једна од познатих словенских дијахроних константа је експанзија суфикса с фонетским елементом „к” и смањење продуктивности $\mathfrak{u}_{-}$суфикса. Та константа развоја словенске деривације дошла је на српски терен мало касније него у другим словенским језицима. Али је ипак суфикс -иц-а као главни феминални суфикс у српском књижевном језику XIX века касније сачувао продуктивност само у исконским моделима. У свим хибридним творбеним типовима на прво место су избили форманти - $\kappa-a$ и -кию- $a$, што смо могли у свом раду статистички приказати на проученом материјалу из Речника Матице српске (Смольская 1987).

Дијахронијско проучавање творбе речи у српском књижевном језику већ је започето у радовима српских лингвиста и њихових колега из других словенских земаља, али до сада је објављено врло мало таквих радова. Међутим, поменута тема представља врло актуелно питање србистике, које се уклапа у актуелну општесловенску проблематику.

\section{ЛИТЕРАТУРА}

Белић А. Савремени српскохрватски језик. Наука о грађену речи. Научна књига, Београд 1949.

Бошковић Р. Развитак суфикса у јужнословенској језичкој заједници. Библиотека Јужнословенског филолога, Београд 1936.

Гухман М. М. Историческая типология и проблема диахронических констант. „Наука”, Москва 1981.

Даничић Ђ. Српска деминуција и аугментащија. Гласник Друштва српске словесности, XII, 1860.

Даничић Ђ. Основе српскога или хрватскога језика. Државна штампарија, Београд 1876. 
Дмитриев П. А., Сафронов Г. И. Вук Караджич и его реборма сербохорватского титературного языка. Изд-во ЛГУ, Ленинград 1984.

Ивић М. Једно поређење Вукова језика с нашим данашғим кюижевним језиком. Зборник за филологију и лингвистику МС, књ. І, Нови Сад 1957.

Изменения в словообразовании и формах существительного и прилагательного в русском титературном языке ХІХ в. „Наука”, 1964.

Караџић В. С. Главна свршиваға суштествителни и прилагателни имена у српском језику. Сабрана дела Вука Караџића, књ. VIII, Београд 1964.

Кашић Ј. Хачићево „Ображаване сриске речи” и Вукова „Главна свршиваға”. Научни састанак слависта у Вукове дане, XIV, Београд 1985.

Ковалник I. I. Про деякі питання слов'янського словотвору. Філологічний збірник. Київ 1958.

Матијашевић Ј. Компаративна проучавана Радосава Бошковића у светлу семантичке деривације. Први лингвистички научни скуп у спомен на Радосава Бошковића, Титоград 1988.

Нещименко Г. П. Очерк деминутивной деривационной системы в истории чешского титературного языка. Academia, Praha 1980.

Ристић О. Лексичко-семантичке одлике творбе именица у неких српских и хрватских романтичарских песника. Јужнословенски филолог, књ. XXVIII, 1969-1970.

Ристић Ст. Морфема -тељ у савременом српскохрватском језику. Наш језик, књ. XXV/4-5, 1982, књ. XXVI/1, 1983.

Смольская А. К. Диахронные константы славянского именного словопроизводства и феминные суфбиксы в сербскохорватском титературном языке. Советское славяноведение, 3, Москва, 1987.

Смольска А. К. Развитие именного словообразования в сербскохорватском титературном языке (фемининативы). Автореферат диссертации на соискание ученой степени доктора филологических наук, Москва 1993.

Стакић М. Деривациона фонетика именища и придева у јужнословенским језищима. Београд 1988.

Сопоставительное изучение словообразования славянских языков. Тезисы международного симпозиума, Москва 1984.

Стевановић М. Савремени српскохрватски језик. І. Научно дело, Београд 1964.

Толстой Н. И. Предисловие. Радосав Бочкович, Основы сравнительной грамматики славянских языков. Высшая школа, Москва 1984.

Ћорић Б. Моциони суфикси у српскохрватском језику. Београд 1982. 
Цвијић О. О неким речима у преводу Новог завета. Јужнословенски филолог, књ. XXVI/1-2, 1963-1964.

\section{РЕЧНИЦИ}

Караџић Вук Ст. Српски рјечник. У Београду 1898.

Речник српскохрватскога књижевног језика. Матица српска, Нови Сад, књ. $1-6,1967-1976$.

Речник српскохрватског књижевног и народног језика. Т. 1-14, САНУ, Београд 1959-1989.

Аделаида Смольская

ЭВОЛЮЦИЯ СЛОВООБРАЗОВАНИЯ В СЕРБСКОМ ЯЗЫКЕ И ЕГО ИЗУЧЕНИЕ

Резюме

Автор считает, что в данный момент актуальны аспекта изучения словообразования: синхронная дериватология, т. е. синхронное описание словообразовательных систем славянских языков, сравнительно-историческая славянская дериватология и диахроническая дериватология каждого славянского языка. Дальше автор дает беглый обзор истории дериватологических исследований сербского языка, начиная с Вука Караджича и кончая современными исследователями. Особое внимание уделяется достижениям в данной области таких исследователей, какими являются Джура Даничич, А. Белич, Р. Бошкович, М. Стеванович, Б. Чорич и некоторые другие. Автор настаивает на установлении синхронных срезов в целях изучения эволюции словообразовательной системы сербского литературного языка XIX и XX вв. Важным моментом актуальных словообразовательных исследований являтся определение диахронных констант. По мнению автора количество работ по историческому словообразованию сербского языка недостаточно, что сказывается и на неадекватном изучении словообразования на общеславянском уровне. Сопоставительные исследования славянских языков вносят ценный вклад в славянскую лигвистическую компаративистику. 